\title{
Influence of Mutagenic Agents on the Integration of the F Episome into the Chromosome of Escherichia coli $\mathrm{K} 12 \mathrm{~F}^{+}$
}

\author{
By MARIANNA RAJCHERT-TRZPIL AND W. T. DOBRZAŃSKI \\ Department of Microbiology and Hygiene, University Medical School, \\ Warsaw, Poland
}

(Accepted for publication 28 May 1968)

\begin{abstract}
SUMMARY
Escherichia coli $\mathrm{F}^{+}$donor bacteria were treated with u.v. radiation, mitomycin $\mathbf{C}$, nitrous acid, hydroxylamine or caffeine, and then incubated for various periods in broth at $37^{\circ}$ before conjugation. U.v. radiation, mitomycin $\mathrm{C}$ and nitrous acid increased the fertility of $\mathrm{F}^{+}$populations, but hydroxylamine and caffeine did not. The maximal effect of u.v. irradiation was obtained after using a dose $50-100 \mathrm{ergs} / \mathrm{mm}^{2}$ and after $45 \mathrm{~min}$. incubation in broth of irradiated bacteria before conjugation. The maximal effect of mitomycin $\mathrm{C}$ occurred after treatment with $\mathrm{I}-3 \mu \mathrm{g}$. $/ \mathrm{ml}$. and after IIO min. incubation in broth. Depending on the strain used, the fertility of the population increased 8-20 times after u.v. irradiation and 5-2I times after mitomycin C. The effect of u.v. irradiation could be photoreactivated up to $50 \%$. Following treatment of strain W 1655 with nitrous acid (0.0I M), a three- to four-fold increase in the yield of conjugation was obtained, although irregularly. Caffeine $(0.01 \%)$ enhanced the effect of u.v. irradiation about two-fold. Chloramphenicol blocked the expression of the effect of u.v. irradiation and mitomycin $\mathrm{C}$. The effect of chloramphenicol was not permanent, because after its removal followed by further incubation the fertility of the $\mathrm{F}^{+}$population increased to the same degree as in the samples in which the bacteria, previously exposed to u.v. radiation or mitomycin $\mathrm{C}$, were incubated in broth without chloramphenicol.
\end{abstract}

\section{INTRODUCTION}

Sexual differentiation in Escherichia coli $\mathrm{K} 12$ depends upon the presence of certain episomes, one of which is the episome $F$. Three sexual types exist: female recipient $\mathrm{F}^{-}$ bacteria and male donors of two types, $\mathrm{F}^{+}$and Hfr. The difference between the male types depends on the location of the $\mathrm{F}$ factor in the cell (Hayes, 1952 a, 1953). In $\mathrm{F}^{+}$ bacteria the episome $F$ is present in the cytoplasm in an autonomous state. Bacteria of the other type, Hfr, arise as a result of the attachment of the F factor to the chromosome of the host cell. Hfr cells have the ability to transfer the chromosome to recipient bacteria (Hayes, 1964; Adelberg \& Pittard, 1965).

The fertility of $\mathrm{F}^{+}$strains, i.e. the ability to transfer the chromosome, depends mainly, if not exclusively, on the presence in populations of these strains of a very small number of $\mathrm{Hfr}$ cells which appear spontaneously in $\mathrm{F}^{+}$populations. Thus, the frequency of recombinants arising in $\mathrm{F}^{+} \times \mathrm{F}^{-}$crosses is strictly dependent on the number of $\mathrm{Hfr}$ cells present in the $\mathrm{F}^{+}$population (Wollman, Jacob \& Hayes, 1956; Jacob \& Wollman, 1956; Hayes, 1964; Adelberg \& Pittard, 1965).

The mechanism of the attachment or integration of the F factor into the chromo- 
some has not as yet been definitively elucidated. A number of observations favour the view advanced by Stern (1963) that recombination takes place between the sex factor and the chromosome. The most convincing argument in support of Stern's view of this mechanism is the data obtained in studies on the integration of $F^{\prime}$ factors (i.e. $F$ episomes harbouring chromosomal genes) into the bacterial chromosome (Scaife \& Gross, 1963).

Less is known about conditions causing the transition of $F$ from the cytoplasm into the chromosome. That u.v. irradiation of $\mathrm{F}^{+}$cells may favour the integration of the $\mathrm{F}$ factor was shown by Hayes (1952 $b$ ) who found that u.v. irradiation of $\mathrm{F}^{+}$donor cells before conjugation can markedly increase the yield of recombinants.

In the present work it was decided to obtain further data concerning conditions favouring the transition of the episome from the cytoplasm into the chromosome, and thus to get some information about the mechanism of integration of F. For this purpose, the influence of some mutagens on the integration of $F$ was examined. Mutagens with a relatively well-known mechanism of action were chosen. The aim of this work was also to investigate the influence of chloramphenicol, photoreactivation and caffeine on u.v. induced processes leading to the integration of $F$.

\section{METHODS}

Strains. Two strains of Escherichia coli $\mathrm{K}$ 12-a wild $\mathrm{F}^{+}$(prototroph str-s) and $\mathrm{F}^{+}$ W 1655 met ton-s str-s $(\lambda)^{-}$-were employed as donors; $E$. coli $\mathrm{K} 12 \mathrm{~F}^{-} \mathrm{P} 678$ thr leu thi lac ton-r str-r $(\lambda)^{-}$served as recipient.

Strains $F^{+}$W 1655 and $F^{-}$P $^{6} 78$ were kindly supplied by Professor W. Hayes, Medical Research Council, Microbial Genetics Research Unit, Hammersmith Hospital, London, and the wild $\mathrm{F}^{+}$strain by Dr J. Greenberg, Palo Alto Medical Research Foundation, California, U.S.A.

Abbreviations denote: thi lack of ability to synthetize thiamine; met lack of ability to synthetize methionine; $t h r$ lack of ability to synthetize threonine; leu lack of ability to synthetize leucine; str streptomycin: sensitivity str-s; resistance $s t r-r$; ton phage $\mathrm{T}_{1}$; sensitivity ton-s; resistance ton-r; lac inability to ferment lactose; gal inability to ferment galactose; $(\lambda)^{-}$non-lysogenic for phage $\lambda ; \lambda-r$ resistant to phage $\lambda$.

Media. Nutrient broth; nutrient agar; minimal agar (Lederberg, 1950); minimal liquid medium (Lederberg, 1950); all media at $\mathrm{pH} 7 \cdot 2$.

Buffers. I. Phosphate buffer $0.02 \mathrm{M}(\mathrm{pH}=7.2)$; II. Phosphate buffer $0.5 \mathrm{M}$ $(\mathrm{pH}=4 \cdot 2)$; III. Phosphate buffer I $\mathrm{M}(\mathrm{pH}=7 \cdot 2)$.

Reagents. Sodium nitrite and hydroxylamine-HCl (Fabryka Odczynnikow Chemicznych, Gliwice, Poland); mitomycin C (Nutritional Biochemicals Corporation, U.S.A.).

Source of u.v. radiation. Westinghouse (U.S.A.) lamp $\mathrm{G}_{3} \mathrm{OT} 8$.

Preparation of bacteria. Cultures ( $18 \mathrm{hr}$ ) of donor and recipient bacteria in $5 \mathrm{ml}$. nutrient broth were diluted with fresh broth I/IO and incubated, with gentle aeration, for $105 \mathrm{~min}$. at $37^{\circ}$. Subsequently, the bacteria were centrifuged down, washed and suspended in buffer I so that the suspensions contained from $8 \times 10^{8}$ to $\mathrm{I} \times 10^{9}$ viable bacteria $/ \mathrm{ml}$. Up to this point the treatment of donor and recipient bacteria was the same. Following these operations, the recipient bacteria were centrifuged down and suspended in the same volume of minimal medium. Thus prepared, the suspensions of recipient bacteria were kept at $0^{\circ}$ until used for conjugation. 
Treatment of donor bacteria. Suspensions of the donor, prepared as above, were centrifuged down and then suspended in the same volume of one of the buffers or broth with the addition of one of the mutagens, or in buffer I for u.v. irradiation. After the removal of the mutagen, the bacteria were twice washed with buffer I, suspended in nutrient broth and incubated at $37^{\circ}$ for the desired period. Following incubation the bacteria were twice washed, resuspended in liquid minimal medium and crossed with the recipient.

Just before conjugation samples were taken from these suspensions and plated on nutrient agar to determine the number of viable bacteria.

In each experiment, in addition to the control tests described in the results section, the following control was made: after preparation of the donor suspension a sample was taken, centrifuged and resuspended in nutrient broth. With this sample the same operations were done as with the other samples except that this control sample was not incubated at $37^{\circ}$ but all procedures were performed at $0^{\circ}$ to $4^{\circ}$. In this paper this control is always designated as no. $\mathrm{I}$.

Conjugations were conducted for $60 \mathrm{~min}$. in a water bath at $37^{\circ}$. Equal volumes of suspensions of recipient bacteria and untreated or treated donor bacteria were mixed. Conjugation was stopped by cooling the test tubes in an ice bath, following which samples were taken for plating on minimal agar with streptomycin $250 \mu \mathrm{g}$. $/ \mathrm{ml}$. to determine the number of $t h r^{+} l e u^{+}$str-r recombinants.

The parental colonies on nutrient agar were counted after $24 \mathrm{hr}$ and the colonies of recombinants after $48 \mathrm{hr}$ of incubation at $37^{\circ}$. The yield of the conjugation was calculated as the frequency of recombinants per $10^{7}$ viable donor bacteria present at the beginning of the conjugation. In each experiment, the frequency of recombinants in the treated trials was compared with that in the untreated control. The bacterial suspensions were always centrifuged at $4^{\circ}$.

\section{RESULTS}

\section{Influence of hydroxylamine}

Before each experiment fresh dilutions of hydroxylamine- $\mathrm{HCl}$ (HA) were prepared in buffer $\mathrm{I}$ and the solutions adjusted to $\mathrm{pH} 7 \cdot 2$.

The results of experiments with HA given in Table I show that hydroxylamine did not increase the fertility of the $\mathrm{F}^{+}$population. The yield of conjugation decreased when the donor bacteria were crossed immediately after treatment with high concentrations

Table 1 . Yield of conjugation after incubation in broth of Escherichia coli $\mathrm{K} I 2 \mathrm{~F}^{+}$ $W 1655$ donor previously treated for $5 \mathrm{~min}$. with various doses of hydroxylamine

\begin{tabular}{cccc}
$\begin{array}{c}\text { Conc. of } \\
\text { hydroxylamine } \\
(M)\end{array}$ & \multicolumn{3}{c}{ Yield of conjugation* after incubation in broth for } \\
\cline { 2 - 3 } & o min. & $45 \mathrm{~min}$. & $90 \mathrm{~min}$. \\
I.5 & $26(45)$ & $104(57)$ & $83(67)$ \\
$0 \cdot 5$ & $30(56)$ & $120(73)$ & $97(132)$ \\
$0 \cdot 1$ & $43(66)$ & $133(89)$ & $85(133)$ \\
O. & $85(90)$ & $113(120)$ & $75(157)$
\end{tabular}

* The results are the mean values of 7 experiments. The yield of conjugation is given in $\%$ of that of the untreated control. The figures in brackets denote the \% of surviving donor bacteria. The number of donor bacteria at the beginning of the experiment was taken as $100 \%$. 
of $\mathrm{HA}$, but after $45 \mathrm{~min}$. incubation in broth the yield was normal, as in the untreated control.

\section{Influence of caffeine}

A suspension of $\mathrm{F}^{+}$bacteria prepared as above was divided into two parts, and both samples were centrifuged. The first served as control no. I. The bacteria in the other sample were suspended in $0.01 \%$ solution of caffeine in broth and incubated $60 \mathrm{~min}$. at $37^{\circ}$. Afterwards, the sample was cooled, the caffeine removed by three washings and the bacteria, suspended in broth, were incubated up to $120 \mathrm{~min}$. at $37^{\circ}$. When caffeine was used in a concentration of $0.01 \%$, no increase in the fertility of $\mathrm{F}^{+}$bacteria was observed; on the contrary, the yield of recombinants was even decreased (I0-50\%). In contrast to the effect of treatment with $\mathrm{HA}$, the effect of caffeine was apparent only after some period of incubation in the broth following removal of the drug.

\section{Influence of nitrous acid}

Before the trials proper, the influence of buffer II on the recombination yield was tested. The results (Table 2) showed that buffer II alone killed a large fraction of $\mathrm{F}^{+}$ bacteria and caused a decrease in the fertility of the cross. For this reason, in the experiments described below, it was decided to compare the frequency of $t h r^{+} l e u^{+}$ str-r recombinants with that of recombinants in the samples treated with buffer II alone.

Table 2. Yield of conjugation after incubation in broth for various periods of Escherichia coli $F^{+} W 1655$ donor previously treated with buffer II

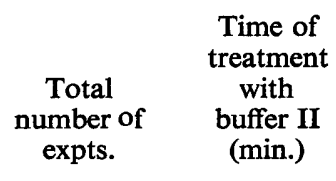

4

3
2

5

$\overbrace{\text { o min. }}^{\text {Yield of conjugation* after incubation in broth for }}$

$4 \mathrm{I}(57)$

19 (I 2)
$80(74)$

$64(55)$
35 (100) $53(86)$

* The yield of conjugation is given in $\%$ of that of the untreated control, figures in brackets denote $\%$ of surviving donor bacteria.

Table 3. Yield of conjugation followed by incubation in broth for various periods of Escherichia coli $\mathrm{F}^{+} \mathrm{W} 1655$ donor treated with $\mathrm{O} \cdot \mathrm{I} \mathrm{M}-\mathrm{HNO}_{2}$

\begin{tabular}{ccccc}
$\begin{array}{c}\text { No. of } \\
\text { expt. }\end{array}$ & $\begin{array}{c}\text { Time of } \\
\begin{array}{c}\text { treatment } \\
\text { with HNO } \\
\text { (min.) }\end{array}\end{array}$ & \multicolumn{2}{c}{ Yield of conjugation* after incubation in broth for } \\
\cline { 3 - 4 } I & I & $45(38)$ & $294(81)$ & $75 \mathrm{~min}$. \\
2 & I & $9(33)$ & $457(82)$ & min. \\
3 & I & $-(29)$ & $274(67)$ & $593(93)$ \\
4 & I & $57(28)$ & $166(74)$ & $285(90)$ \\
5 & 2 & $62(17)$ & $127(19)$ & $122(100)$ \\
6 & 5 & $44(18)$ & $100(22)$ & $303(16)$ \\
7 & 5 & $10(18)$ & $27(64)$ & $420(33)$
\end{tabular}

* The yield of conjugation is given in $\%$ of that of untreated control, figures in brackets denote the $\%$ of surviving donor bacteria. 
Four samples, each containing $9 \mathrm{ml}$. of the $\mathrm{F}^{+} \mathrm{W} 1655$ suspension, were prepared. After centrifugation, the bacteria in two samples were suspended in $3 \mathrm{ml}$. nitrous acid (NA) solution (O.I M and $0.01 \mathrm{M}$ ). The bacteria in the third tube were suspended in $3 \mathrm{ml}$. of buffer II only. All these samples were incubated for different periods at $37^{\circ}$. Subsequently, NA was neutralized by the addition of $25 \mathrm{ml}$. phosphate buffer III. The samples were centrifuged, and the bacteria resuspended in $9 \mathrm{ml}$. of broth and incubated for up to $75 \mathrm{~min}$. at $37^{\circ}$. The bacteria in the fourth tube were treated as control no. I.

The results of these experiments (Table 3) show that treatment of the donor cells with NA in $0 . I \mathrm{M}$ concentration may cause some increase in fertility. Nitrous acid in a $0.01 \mathrm{M}$ concentration did not exert any influence on the yield of recombination. The results are not presented as mean values because, as the table shows, differences between the results of individual experiments were considerable and the maximal increase in the fertility of the $\mathrm{F}^{+}$population occurred at a variable time during the additional incubation period after treatment and before mating.

Interpretation of these experiments should be treated with caution due to the lethal effect of buffer II and to the variation between experiments.

\section{Table 4. Yield of conjugation after incubation in broth for various periods of Escherichia coli $F^{+} W 1655$ donor after u.v. irradiation}

\begin{tabular}{|c|c|c|c|c|c|c|}
\hline \multirow{2}{*}{$\begin{array}{r}\text { u.v.-dose } \\
\text { ergs/mm. }\end{array}$} & \multicolumn{6}{|c|}{ Yield of conjugation* after incubation in broth for } \\
\hline & o min. & $15 \mathrm{~min}$. & $30 \mathrm{~min}$. & $45 \mathrm{~min}$. & $60 \mathrm{~min}$. & $90 \mathrm{~min}$. \\
\hline 50 & $58(89)$ & $262(87)$ & $574(71)$ & $820(8 I)$ & 492 (9I) & 401 (I02) \\
\hline 100 & -- & -- & - & $740(80)$ & -- & -- \\
\hline 200 & -- & -- & -- & $407(65)$ & - - & - - \\
\hline 400 & $28(37)$ & $126(38)$ & $192(35)$ & $220(36)$ & $180(35)$ & 87 (39) \\
\hline
\end{tabular}

* The yield of conjugation is given in \% of the non-irradiated control, figures in brackets denote the $\%$ of surviving donor bacteria.

\section{Effect of u.v. irradiation}

Influence of u.v. on the integration of the F factor into the chromosome of Escherichia coli $\mathrm{K}_{12} \mathrm{~F}^{+}$. A suspension of $\mathrm{F}^{+} \mathrm{W} \mathrm{I} 655$ was divided into 5 parts. The first sample was left unirradiated and served as control no. I. The remaining samples were irradiated with 50, 100, 200 and $400 \mathrm{ergs} / \mathrm{mm} .^{2}$ doses of u.v. radiation, respectively. After the exposure, all samples were centrifuged, and the bacteria resuspended in broth to the same volume and incubated up to $90 \mathrm{~min}$. The samples were protected against photoreactivation. The results of this kind of experiment are summarized in Table 4.

The influence of u.v. radiation on the yield of conjugation is considerable. Irradiation of $\mathrm{F}^{+}$donor bacteria with u.v. radiation $50 \mathrm{ergs} / \mathrm{mm} .{ }^{2}$ decreased the yield of recombinants by about $40 \%$, and with $400 \mathrm{ergs} / \mathrm{mm} .^{2}$ by about $70 \%$, when the donor population was mated immediately after irradiation. However, the fertility of the donor strain markedly increased when the irradiated bacteria were incubated in broth before conjugation. The intensity of this effect of u.v. radiation depended on the radiation dose and the time of post-treatment incubation in broth. With $\mathrm{W} 1655 \mathrm{~F}^{+}$bacteria, the maximal increase in the fertility of the population was obtained after using small doses of radiation (50-100 ergs $/ \mathrm{mm}^{2}$ ) followed by $45 \mathrm{~min}$. incubation in broth. For maximal expression of the radiation effect, the same period of incubation was also needed following treatment with a much higher dose, i.e. 400 ergs. $/ \mathrm{mm} .^{2}$. 
Influence of caffeine on the integration of the $F$ episome into the chromosome of $u . v$. irradiated donor bacteria. A suspension of $\mathrm{W} \mathrm{I}_{555} \mathrm{~F}^{+}$bacteria prepared in the normal way was divided into two samples. An unirradiated sample was used as control no. I. Immediately after a $50 \mathrm{ergs} / \mathrm{mm}^{2}$ dose of radiation, the other sample was divided into 5 parts. All samples were centrifuged and resuspended in broth both with and without caffeine (I, $0 . \mathrm{I}, 0.0 \mathrm{I}, 0.00 \mathrm{I} \%$ ) concentration and incubated for $45 \mathrm{~min}$. at $37^{\circ}$. Afterwards, the caffeine was removed by washing the bacteria twice with buffer $\mathrm{I}$, before mating with the recipient.

Table 5. Yield of conjugation after u.v.-irradiation/5o ergs/mm..$^{2}$ of $F^{+}{ }_{W} 1655$ donor and after 45-minute incubation with or without caffeine

Total number of expts. 5

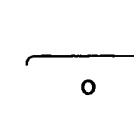

802 (9I)

Yield of conjugation* concentration of caffeine $(\%)$

0.001

I,370 (90)

$0 \cdot 1$

$510(87)$

I $60(77)$

* The yield of conjugation is given in \% of that of non-irradiated and untreated control. The yields of crosses in which the non-irradiated donor was treated with various doses of caffeine fluctuated from 50 to $100 \%$. The figures in brackets denote the \% of surviving bacteria.

The results of these experiments (Table 5) indicated that the addition of caffeine to the culture of irradiated $\mathrm{F}^{+}$bacteria increased or decreased the influence of u.v. irradiation on the recombination yield depending on the concentration. After incubation of irradiated bacteria in the presence of $0.01 \%$ caffeine, the frequency of recombinants was double that in the case of a population of irradiated bacteria incubated in broth only. However, I \% caffeine considerably inhibited the processes leading to the increase in the fertility of the u.v. irradiated donor population.

Influence of chloramphenicol on the integration of episome $F$ into the chromosome of u.v. irradiated $W 1655 F^{+}$bacteria. A suspension of donor bacteria was divided into two parts. One of them was u.v. irradiated with $50 \mathrm{ergs} / \mathrm{mm} .{ }^{2}$. Subsequently, the suspensions were divided into five samples: three unirradiated, two irradiated. After centrifugation, the samples were treated as follows: (I) unirradiated bacteria were suspended in broth and served as control no. I ; (2) unirradiated bacteria were suspended in broth and incubated $45 \mathrm{~min}$. at $37^{\circ}$ (control no. 2); (3) irradiated bacteria were suspended in broth and incubated $45 \mathrm{~min}$. at $37^{\circ}$ to determine the stimulating effect of u.v. radiation on the recombination yield (control no. 3); (4) unirradiated bacteria were suspended in broth with chloramphenicol (CM) $4 \mu \mathrm{g} . / \mathrm{ml}$. and incubated $45 \mathrm{~min}$. at $37^{\circ}$. Afterwards, to remove the chloramphenicol, the bacteria were twice washed in buffer I, and once more incubated at $37^{\circ}$ for up to $120 \mathrm{~min}$. in broth only. The control (no. 4) served to show the influence of chloramphenicol only; (5) u.v. irradiated bacteria were treated exactly as was control no. 4; this was the trial proper.

The results of these experiments (Table 6) showed that incubation of u.v. irradiated $\mathrm{F}^{+}$bacteria in the presence of chloramphenicol blocked expression of the stimulating effect of u.v. radiation on the integration of the $\mathrm{F}$ episome. However, this block was reversible because, after removal of the chloramphenicol, the yield of conjugation in the u.v.-treated and chloramphenicol-treated population reached the same degree as that in an irradiated $\mathrm{F}^{+}$population not treated with chloramphenicol. These results also showed that the presence of chloramphenicol during incubation before the 
conjugation: (i) did not change the frequency of recombinants produced by unirradiated $\mathrm{F}^{+}$bacteria, (ii) did not favour the integration of the episome nor 'cure' lesions induced by u.v. radiation responsible for the increase in the fertility of the irradiated donor bacteria.

Table 6. The influence of chloramphenicol on the yield of conjugation in Escherichia coli $\mathrm{F}^{+} W 1655$ donor $u . v$.-irradiated (50 ergs $/ \mathrm{mm}^{2}$ )

Yield of conjugation*

\begin{tabular}{|c|c|c|c|}
\hline $\mathbf{F}^{+}$bacte & $\begin{array}{l}\text { non-irradiated and incubated } \\
\text { in broth for } 45 \mathrm{~min} \text {. }\end{array}$ & $\mathbf{F}^{+}$bacte & $\begin{array}{l}\text { u.v.-irradiated and incubated } \\
\mathrm{n} \text { broth for } 45 \mathrm{~min} \text {. }\end{array}$ \\
\hline $\begin{array}{c}\text { no } \\
\text { chloram- } \\
\text { phenicol }\end{array}$ & +Chloramphenicol $4 \mu \mathrm{g} . / \mathrm{ml}$. & $\begin{array}{c}\text { no } \\
\text { chloram- } \\
\text { phenicol }\end{array}$ & +Chloramphenicol $4 \mu \mathrm{g} . / \mathrm{ml}$. \\
\hline 79 & 76 & 805 & 102 \\
\hline
\end{tabular}

After removal of chloramphenicol, and additional incubation in fresh broth for (min.)

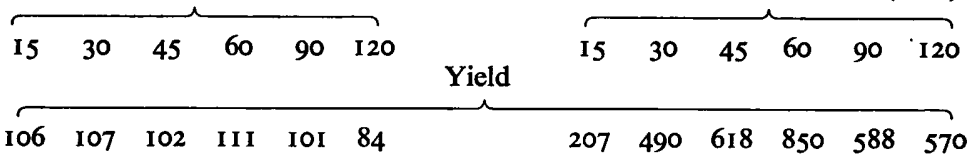

* The experimental method is described in the text. The results are the mean value of 4 experiments. The yield of conjugation is given in $\%$ of that of the non-irradiated control.

Table 7. Photoreactivation of u.v. stimulated integration of the $F$ episome in Escherichia coli $\mathrm{K} I 2 \mathrm{~F}^{+}$wild-type strain

\begin{tabular}{|c|c|c|c|c|}
\hline $\begin{array}{l}\text { Time of photo- } \\
\text { reactivation or } \\
\text { of incubation } \\
\text { in dark } \\
\text { (min.) }\end{array}$ & $\begin{array}{l}\text { Yield of con- } \\
\text { jugation after u.v. } \\
\text { irradiation and } \\
\text { incubation in } \\
\text { dark }(x)\end{array}$ & $\begin{array}{c}\text { Yield of con- } \\
\text { jugation after u.v. } \\
\text { irradiation and } \\
\text { photoreactivation } \\
(y)\end{array}$ & $\begin{array}{l}\text { Coefficient of } \\
\text { photoreactivation } \\
(x / y)\end{array}$ & $\begin{array}{c}\text { Photo- } \\
\text { reactivation } \\
\%\end{array}$ \\
\hline 15 & 700 & 694 & I & 0 \\
\hline 30 & 8,987 & 6,150 & $I \cdot 4$ & 32 \\
\hline 45 & I $3,45 I$ & 6,914 & $x \cdot 9$ & 49 \\
\hline
\end{tabular}

The bacteria were u.v.-irradiated with $250 \mathrm{ergs} / \mathrm{mm} .^{2}$ which inactivated about $60 \%$ of the bacteria, and increased the frequency of recombinants about 20 times. The yield of crosses is given as the frequency of $t h r^{+} l e u^{+} s t r-r$ recombinants $/ 10^{7}$ viable donor bacteria.

Photoreactivation of the effect of u.v. radiation. We did not succeed in photoreactivating either the inactivation or the fertility stimulation effect of u.v. radiation in Escherichia coli $\mathrm{K}$ I 2 W 1655 . For this reason, in this set of experiments, we used a photoreactivable $E$. coli $\mathrm{K}$ I2 $\mathrm{F}^{+}$wild-type strain, obtained from Dr J. Greenberg.

Photoreactivation (PR) was done in a waterbath at $37^{\circ}$. Two 'Episkop' bulbs ('Tungsram' $500 \mathrm{~W}$ ), placed at a distance of $17 \mathrm{~cm}$. from the test tube containing the irradiation suspension, served as light source for $\mathrm{PR}$. A filter of aqueous $\mathrm{CuSO}_{4}$ solution was placed between the light source and the waterbath. The method used in the experiments on photoreactivation was as follows. A suspension of wild type $\mathrm{F}^{+}$ bacteria was divided into two parts. One was used as control no. I, and the other was 
irradiated with a $250 \mathrm{ergs} / \mathrm{mm}^{2}$ dose of u.v. radiation. When this dose was used, the effect of PR was higher than after a dose of $50 \mathrm{ergs} / \mathrm{mm} .^{2}$. Immediately after irradiation, one sample of the irradiated suspension was photoreactivated up to $45 \mathrm{~min}$. and the other incubated in the dark for the same period. After treatment with $250 \mathrm{ergs} / \mathrm{mm} .^{2}$ dose of u.v. radiation, the survival of the wild-type bacteria was about $40 \%$, and the frequency of recombinants increased about 20 times.

The results presented in Table 7 showed that it was possible to photoreactivate the stimulating effect of u.v. radiation on the conjugation yield in the Escherichia coli $\mathrm{K} 12 \mathrm{~F}^{+}$wild-type strain used. Under the conditions of these experiments, after irradiation with visible light for 45 min., this photoreactivation decreased by about $50 \%$ the frequency of recombinants.

\section{Influence of mitomycin $C$}

Influence of mitomycin $C$ on the integration of the $F$ factor into the chromosome of Escherichia coli $\mathrm{K} I 2 \mathrm{~F}^{+}$. A suspension of donor bacteria, prepared in the normal way, was divided into two parts, and the bacteria centrifuged down. One sample served as control no. I. The bacteria from the other sample were centrifuged down, resuspended

Table 8. Escherichia coli $\mathrm{K} I 2$. Yield of crosses after incubation in broth for various periods of $\mathrm{F}^{+}$donors previously treated with mitomycin $C$ (I $\mu \mathrm{g} . / \mathrm{ml}$.) for Io min. at $37^{\circ}$

\begin{tabular}{|c|c|c|c|c|c|c|c|c|}
\hline \multirow[b]{2}{*}{ Strain } & \multirow{2}{*}{$\begin{array}{l}\text { No. of } \\
\text { expts. }\end{array}$} & \multicolumn{7}{|c|}{ Yield of conjugation* after incubation in broth for } \\
\hline & & 0 min. & $30 \mathrm{~min}$. & $60 \mathrm{~min}$. & $90 \mathrm{~min}$. & $110 \mathrm{~min}$. & $130 \mathrm{~min}$. & $150 \mathrm{~min}$. \\
\hline Wild $\mathrm{F}^{+}$ & 3 & $\begin{array}{c}93 \\
(76)\end{array}$ & $\begin{array}{l}\mathbf{I}, 240 \\
(73)\end{array}$ & $\begin{array}{l}2,000 \\
(73)\end{array}$ & $\begin{array}{l}2,080 \\
(74)\end{array}$ & $\begin{array}{l}2,565 \\
(74)\end{array}$ & $\begin{array}{l}2,150 \\
\text { (70) }\end{array}$ & $\begin{array}{l}\text { I,710 } \\
(70)\end{array}$ \\
\hline W $1655 \mathrm{~F}^{+}$ & 8 & $\begin{array}{l}89 \\
(65)\end{array}$ & $\begin{array}{l}210 \\
(79)\end{array}$ & $\begin{array}{c}355 \\
(87)\end{array}$ & $\underset{(70)}{474}$ & $\begin{array}{c}530 \\
(70)\end{array}$ & $\begin{array}{c}394 \\
(76)\end{array}$ & $\begin{array}{c}312 \\
(80)\end{array}$ \\
\hline
\end{tabular}

* The yield of conjugation is given in \% of that of the untreated control, figures in brackets denote the $\%$ of surviving donor bacteria.

in broth containing mitomycin C I $\mu \mathrm{g}$. $/ \mathrm{ml}$. and incubated Io min. at $37^{\circ}$. Subsequently, the samples were cooled, the antibiotic removed by two washings with buffer $I$, and the bacteria mated after various periods of incubation in fresh broth at $37^{\circ}$.

The results of these experiments (Table 8) showed that the yield of conjugation in the $\mathrm{F}^{+}$system markedly increased when the donor bacteria were treated with mitomycin $\mathrm{C}$ before mating. However, the increase in conjugation yield was detectable only after a definite period of incubation in broth after mitomycin $\mathrm{C}$ treatment; the maximal increase occurred after treatment with low concentrations ( $\mathrm{I}-3 \mu \mathrm{g} . / \mathrm{ml}$.) followed by about I IO min. incubation. Higher concentration of mitomycin C (IO $\mu \mathrm{g} . / \mathrm{ml}$.) caused a smaller increase in the frequency of recombinants. The bacteria in the samples which were not incubated after treatment with the antibiotic did not show any enhancement of fertility. In previous work, in which the influence of mitomycin $C$ on Escherichia coli $\mathrm{F}^{+}$was studied, the consequences of treatment with mitomycin $\mathrm{C}$ was observed only immediately after removal of the mutagen (Driskel-Zamenhof \& Adelberg, 1963; Reich, Shatkin \& Tatum, 1961).

The effect of mitomycin $\mathrm{C}$ was much greater on the wild-type Escherichia coli $\mathrm{K}$ I2 $\mathrm{F}^{+}$strain than on $\mathrm{W} \mathrm{I} 655 \mathrm{~F}^{+}$. With the wild-type strain about a 25 -fold enhancement 
of conjugation yield was obtained; with $\mathrm{W}$ I655 $\mathrm{F}^{+}$the fertility increased about five times. Throughout the post-treatment incubation period in broth (up to $150 \mathrm{~min}$.) the number of viable donor bacteria remained constant, i.e. no multiplication occurred.

Influence of chloramphenicol on the integration of the $F$ episome into the chromosome of mitomycin C-treated Escherichia coli $F^{+}$. These experiments were done in the same manner as described above where the effect of chloramphenicol on the integration of $F$ in u.v. irradiated donors was studied, except that instead of u.v. radiation the bacteria were treated with mitomycin $\mathrm{C}$ at $\mathrm{I} \mu \mathrm{g}$. $/ \mathrm{ml}$. for $\mathrm{IO} \mathrm{min}$. The results of these experiments are given in Table 9. The influence of chloramphenicol on the fertility of

Table 9. The influence of chloramphenicol on the yield of conjugation in Escherichia coli $\mathrm{F}^{+}$donors previously treated with mitomycin $\mathrm{C}$

Yield of crosses after treatment with mitomycin $\mathbf{C}$ and incubation in broth for $110 \mathrm{~min}$.

\begin{tabular}{|c|c|c|c|c|}
\hline Strain & $\begin{array}{l}\text { No } \\
\text { chloramphenicol }\end{array}$ & \multicolumn{3}{|c|}{ + Chloramphenicol $4 \mu \mathrm{g} . / \mathrm{ml}$. } \\
\hline \multirow[t]{4}{*}{$\begin{array}{l}\text { Wild F+ } \\
\text { W I655 } \mathrm{F}^{+}\end{array}$} & $\begin{array}{c}1,970^{*} \\
413\end{array}$ & \multirow{2}{*}{\multicolumn{3}{|c|}{$\begin{array}{l}\text { After removal of chloramphenicol, and further } \\
\text { incubation in fresh broth for }\end{array}$}} \\
\hline & & & & \\
\hline & Strain & $90 \mathrm{~min}$. & I Io min. & $150 \mathrm{~min}$. \\
\hline & $\begin{array}{l}\text { Wild F+ } \\
\text { W } 1655 \mathrm{~F}^{+}\end{array}$ & $\begin{array}{r}1,942 \\
221\end{array}$ & $\begin{array}{r}1,920 \\
409\end{array}$ & $\begin{array}{r}1,731 \\
129\end{array}$ \\
\hline
\end{tabular}

- In the case of the wild-type strain, the results are the mean value of 2 experiments; in the case of w 1655 strain, of 4 experiments. The yield of conjugation is given as a percentage of that obtained with untreated controls.

mitomycin $\mathrm{C}$-treated $\mathrm{F}^{+}$bacteria was analogous to that on the u.v. irradiated population. Chloramphenicol did not permit expression of the fertility-stimulating effect of mitomycin C. Similarly, the effect of chloramphenicol was not irreversible because after its removal during the post-treatment incubation period the increase in fertility occurred to the same extent as in the mitomycin C-treated population.

Attempt to photoreactivate the fertility-stimulating effect of mitomycin $C$. Under the conditions of experiments with chloramphenicol (above) we were unable to show photoreactivation of the activity of mitomycin C.

\section{DISCUSSION}

It is known that DNA is the primary target of activity of mutagenic agents used (e.g. Szybalski \& Iyer, 1964; Tessman, 1962; Geiduschek, I96I ; Marmur et al. 196I). Each of these agents causes various types of lesions in DNA. However, some of those which occur after treatment with these agents are of the same type (e.g. deletions or additional inter-strand cross-links appear). It might be suggested that the activity of various mutagens as observed in the present work was a result of the same type of damage, occurring in chromosomal and/or episomal DNA. Against this view, the fact might be adduced that a considerable part of the ultraviolet radiation effect (about $50 \%$ ) 
could be photoreactivated. Information available so far (e.g. Setlow, Boling \& Bollum, 1965) indicates that only dimers of pyrimidine bases can be photoreactivated, and that dimerization as a type of damage in DNA occurs only after treatment with u.v. radiation.

The increase in the fertility of donors is not, however, a general property of mutagens; neither hydroxylamine nor caffeine caused an increase of recombinants. Of the mutagens used, hydroxylamine was the one to act most specifically, causing only point mutations (Tessman, Poddar \& Kumar, 1964), but it did not increase the fertility of $\mathrm{F}^{+}$cultures. However, u.v. radiation, mitomycin $\mathrm{C}$ and nitrous acid cause, in addition to point mutations, mutational changes on longer fragments of DNA. Caffeine, on the other hand, is a mutagen only in very few systems (see Dobrzański, 1965).

Damage by u.v. radiation in DNA and the inhibition of DNA synthesis activate enzymatic repair mechanisms (Boyce \& Howard-Flanders, 1964a; Howard-Flanders et al. 1966). Boyce \& Howard-Flanders (1964b) suggested that the mechanism which repairs DNA after treatment with mitomycin $C$ is the same as that which operates in the case of u.v. radiation. Thus, the possibility must be considered that the effect of mutagens in stimulating the fertility of $\mathrm{F}^{+}$bacteria may be caused by the activation of mechanisms which repair DNA and also favour a recombination of the two DNA fragments, the episomal and the chromosomal. The importance of the mechanisms which repair the injuries may perhaps be emphasized by the experiments in which $\mathrm{F}^{+}$bacteria, after u.v. irradiation but before conjugation, were incubated in the presence of caffeine or chloramphenicol: caffeine enhanced the fertility-increasing effect of u.v. radiation. According to present views, caffeine is believed to inhibit the activity of the enzymic system which removes in the dark the changes in DNA caused by u.v. radiation (Lieb, I96I; Metzger, 1964).

The results of the present work show that an increase in the fertility of $\mathrm{F}^{+}$population was only revealed after a definite period of incubation of the donor in broth alone-after the removal of the mutagen before conjugation. At a certain time of such incubation, the increase in fertility reached its peak, after which, as the incubation was continued, fertility decreased. The fact that, to obtain the maximal effect after treatment with various mutagens, incubation must last for various periods indicates that the processes leading to increased fertility in $\mathrm{F}^{+}$culture take time. This is confirmed by the observations on the influence of chloramphenicol on the increase in the fertility of the $\mathrm{F}^{+}$donor caused by u.v. radiation and mitomycin $\mathrm{C}$. The incubation of donor bacteria, previously treated with a mutagen, in broth with chloramphenicol prevented an increase in the fertility of an $\mathrm{F}^{+}$population. Chloramphenicol inhibits primarily the synthesis of protein, including enzymes which may perhaps be active in the process of integration of the episome into chromosomal DNA; this inhibitory effect of chloramphenicol is reversible and not lasting. Chloramphenicol inhibits the spontaneous integration of the $\mathrm{F}$ factor into the chromosome, while not exerting any influence on Hfr bacteria in which it does not decrease the yield recombination (Rajchert-Trzpil, 1965). The frequency of recombinants after having reached a maximum, decreased on subsequent incubation. It could possibly be explained by some kind of unstable attachment of the $\mathrm{F}$ episome to the chromosome, differing from the greater stability of spontaneously formed attachments. 


\section{REFERENCES}

Adelberg, E. A., Pittard, J. (1965). Chromosome transfer in bacterial conjugation. Bact. Rev. 26, 161 .

BOYCE, R. P. \& HowARD-FLANDERS, P. (1964a). Release of ultraviolet light-induced thymine dimers from DNA in E. coli K 12. Proc. natn. Acad. Sci., U.S.A. 51, 293.

Boyce, R. P. \& Howard-Flanders, P. $(1964 b)$. Genetic control of DNA breakdown and repair in E. coli $\mathrm{K} I 2$ treated with mitomycin C or ultraviolet light. Z. Vererb. Lehre 95, 345.

DobrzaŃskI, W. T. (1964). Thesis: O działaniu letalnym i mutagennym promieniowania UV na szczep gronkowca złocistego 209P. Ośrodek Wydawnictw Akademii Medycznej w Warszawie, p. 102.

DobrzaŃski, W. T. (1965). Działanie letalne i mutagenne promieniowania ultrafioletowego na bakterie. Post. Mikrobiol. 4, 3.

Driskel-Zamenhof, P. J. \& Adelberg, E. A. (1963). Studies on the chemical nature and size of the sex factors of $E$. coli $\mathrm{K}$ 12. J. molec. Biol. 6,483 .

GeIDUSCheK, E. P. (1961). 'Reversible' DNA. Proc. natn. Acad. Sci., U.S. 47, 950.

HAYES, W. (1952a). Recombination in $E$. coli $\mathrm{K}$ I2: unidirectional transfer of genetic material. Nature, Lond. 169, 118.

HAYES, W. $(1952 b)$. Genetic recombination in Bact. coli $\mathrm{K} 12$ : analysis of the stimulation effect of ultraviolet light. Nature, Lond. 169, 1017.

HAYES, W. (I953). Observations on transmissible agent determining sexual differentiation. J. gen. Microbiol. 8, 72.

HAYEs, W. (1964). The Genetics of Bacteria and their Viruses. Oxford: Blackwell Scientific Publications.

HowARD-Flanders, P., BOYCE, R. P. \& THERRIOT, L. (1966). Three loci in Escherichia coli $\mathrm{K}$ I 2 that control the excision of pyrimidine dimers and certain other mutagen products from DNA. Genetics 53, I 19.

JACOB, F. \& Wollman, E. L. (1956). Recombinaison génétique et mutants de fertilité chez E. coli. C. r. hebd. Sèanc. Acad. Sci., Paris 242, 303.

LEDERBERG, J. (1950). Isolation and characterization of biochemical mutants of bacteria. Meth. med. Res. 3, 5 .

LIEB, M. (I961). Enhancement of UV-induced mutation in bacteria by caffeine. Z. Vererb. Lehre 92 416.

Marmur, J., Anderson, W. F., Mattews, L., Berns, K., Gajewska, E., Lane, D. \& Doty, P. (1961). The effect of ultraviolet light on the biological and physical chemical properties of deoxyribonucleic acids. J. cell. comp. Physiol. 58, Suppl. I, 33 .

METZGER, K. (1964). On the dark-reactivation mechanism in ultraviolet irradiated bacteria. Biochem. biophys. Res. Comm. 15, I01.

RAJCHERT-TrzPIL, M. (1965). The influence of chloramphenicol on the conjugation yield in $E$. coli K 12. Bull. Acad. polon. sci. Cl. VI. I3, 21 I.

Rrich, E., ShatkIn, A. J. \& TAtum, E. L. (196I). Bacteriocidal action of mitomycin C. Biochim. biophys. Acta 53, 132.

ScaIFe, J. \& Gross, J. D. (1963). The mechanism of chromosome mobilization by an F-prime factor in E. coli $\mathrm{K}$ I2. Genetic Res. Camb. 4, 328.

Setlow, J. K., Boling, M. E. \& Bollum, E. J. (1965). The chemical nature of photoreactivable lesions in DNA. Proc. natn. Acad. Sci., U.S. 53, 1430.

Stern, C. (1963). Methodology in Basic Genetics. Ed. by W. L. Burdette. San Francisco: Holden-Day, Inc.

SZYBALSKI, W. \& IYER, V. N. (1964). Crosslinking of DNA by enzymatically or chemically activated mitomycins and porfiromycins, bifunctionally 'alkylating' antibiotics. Fed. Proc. Fedn. Am. Socs exp. Biol. 23, 946.

Tessman, I. (1962). The induction of large deletions by nitrous acid. J. molec. Biol. $5,442$.

Tessman, I., Poddar, R. K. \& Kumar, S. (1964). Identification of the altered bases in mutated singlestranded DNA. I. In vitro mutagenesis by hydroxylamine, ethylmethanesulfonate and nitrous acid. J. molec. Biol. 9, 352.

Wollman, E. L., JACOB, F. \& HAYES, W. (1956). Conjugation and genetic recombination in E. coli K 12. Cold. Spring Harb. Symp. quant. Biol. 21, I4I. 